\title{
YOUTH ENTREPRENEURSHIP DEVELOPMENT: A REVIEW OF LITERATURE AND TEN-YEAR RESEARCH RESULTS
}

\author{
UDC: 005.5-053.6(497.11) \\ Review Paper

\section{Dragan ĆOĆKALO ${ }^{1}$, Dejan ĐORĐEVIĆ ${ }^{1}$, Srđan BOGETIĆ ${ }^{2}$, Mihalj BAKATOR ${ }^{3}$} \\ ${ }^{1}$ University of Novi Sad, Technical Faculty "Mihajlo Pupin”, 23000 Zrenjanin, Đure Đakovića bb, \\ Republic of Serbia \\ ${ }^{2}$ Belgrade Business and Arts Academy of Applied Studies, 11000 Belgrade, Kraljice Marije 73, \\ Republic of Serbia \\ ${ }^{3}$ University of Novi Sad, Technical Faculty "Mihajlo Pupin”, 23000 Zrenjanin, Đure Đakovića bb, \\ Republic of Serbia \\ E-mail: mihalj.bakator@uns.ac.rs
}

Paper received: 12.09.2020.; Paper accepted: 10.10.2020.

\begin{abstract}
Entrepreneurship plays an important role in economic development. Further, the concept of entrepreneurship has been argued as the important factor in overall economic growth. As youth unemployment rates are high both in developing and developed countries, improving the environment for entrepreneurial activities is a necessity as to increase youth entrepreneurship potential. In this paper, the results of ten-year research on youth entrepreneurship are reviewed. In this study 5670 participants - high school students, and university students from the Republic of Serbia, took part. Also, other literature sources were analyzed. The main goal of this paper was identify and determine the potential influence of students' attitudes regarding entrepreneurship and their intention to start a business. The paper analyzes the existing body of literature in order to provide a thoroughly investigated and concisely presented "image" in the domain of youth entrepreneurship. Hence, effectively provide a solid base for future research.
\end{abstract}

Keywords: Youth entrepreneurship; Development; Attitudes; Intentions; Business; Serbia.

\section{INTRODUCTION}

Entrepreneurship in developing countries have the potential to push economic development forward and it can create a sustainable environment for economic growth (Bakator, Đorđević, Ćoćkalo, Nikolić, \& Vorkapić, 2018; Bruton, Ahlstrom, \& Obloj, 2008; Crudu, 2019; Lamrani et al., 2016). Similarly to entrepreneurship, small and mediumsized enterprises (SMEs) have an important role when it comes to economic prosperity, and it can significantly contribute to higher standards of living and an overall reduction of unemployment rates (Bollingtoft, Ulhoi, 2005; Bostan, Lazar, Asalos, Munteanu, \& Horga, 2019). Evidently, SMEs and entrepreneurship represent complex mechanisms and carriers of employment, development, and innovation (Wellalage, \& Fernandez, 2019). This potentially indicates that SMEs and new businesses, which rely on entrepreneurial activities, have the capacity to increase innovation intensity and to create new value. Additionally, entrepreneurial activities in an organization have a positive influence on overall organizational wealth (Antoncic, \& Hisrich, 2004; Khalid, Ahmed, Tundikbayeva, \& Ahmed, 2019). From here, it can be assumed that entrepreneurship doesn't only affect the creation of value on an organizational level, but also positively influences job creation, growth in productivity, and overall economic development. Now, as for economic development, entrepreneurial activities can depend on it, and this results in various degrees of entrepreneurship across countries and even regions within a single country (Acs, Desai, \& Hessels, 2008; Doran, McCarthy, \& O’Connor, 2018).

Furthermore, it was discussed that entrepreneurial activities rather come from an individual than the environment therefore it is more important to 
D. Coćkalo Youth entrepreneurship development:

et al. A review of literature and ten-year research results

develop entrepreneurial knowledge and competencies compared to providing resources and infrastructure (Man, Lau, \& Chan, 2002; Shahab, Chengang, Arbizu, \& Haider, 2018). However, in a slightly earlier study, contradictory findings were noted, and it was argued that resource-based stimulation positively affects entrepreneurial activities. More precisely, individuals who are not prone to entrepreneurship may consider starting their own business if there are adequate incentives in the form of resources or infrastructure (Olugbola, 2017). Further, besides the importance of entrepreneurship, the concept of youth entrepreneurship can be viewed as an even more crucial component to economic prosperity. Namely, youth entrepreneurship reduces youth unemployment rates, improves the innovation development, and overall improves economic growth (Ćoćkalo, Đorđević, Nikolić, Stanisavljev, \& Terek, 2017; Manolova, Edelman, Shirokova, \& Tsukanova, 2019).

The complexity of entrepreneurial activities requires extensive research on entrepreneurial intent. The concept of entrepreneurship intentions presents a key element and construct in entrepreneurial research (Choi, \& Shepherd, 2004; Neneh, 2019; Thompson, 2009; Wilson, Kickul, \& Marlino, 2007). In this current review paper, youth entrepreneurship, as an important element of reducing youth unemployment rates is analyzed. The importance of youth entrepreneurship lies in its role in the process of economic development and economic growth (Ćoćkalo, Đorđević, Nikolić, Stanisavljev, \& Terek, 2017; Ćoćkalo, et al., 2019). Further, the results of ten-year research are reviewed and discussed. Overall, 5670 participants were included in the research. The participants were high school and university students from the University of Novi Sad and the University of Belgrade.

The paper includes three main sections (excluding the Introduction and Conclusion sections). The first section conducts a thorough literature review on youth entrepreneurship and factors which may affect entrepreneurial activities. The second section reviews the mentioned ten-year research. Finally, the obtained information from the review is discussed.

\section{LITERATURE REVIEW}

The concept of entrepreneurship can be defined as a group of actions conducted by individuals and/or groups where the main goal is to create new opportunities that are not existent nor part of the already established organizations (Carree, \& Thurik, 2010). It was also noted that entrepreneurship is more tied to individuals and that its potential is mainly contained on a lower level, rather than on a macro-economic level. As noted earlier, entrepreneurship positively affects economic growth (Ahlstrom, Chang, \& Cheung, 2019; Sergi, Popkova, Bogoviz, \& Ragulina, 2019), while youth entrepreneurship also has a positive effect on economic development as well as on youth unemployment rates (MarianaCristina, 2014). When it comes to the macro-level, it was noted that culture is a facilitating predicting when it comes to the effects of institutional, economic, and social factors on entrepreneurship (Pinillos, \& Reyes, 2011; Stephan, \& Uhlaner, 2010; Walsh, \& Winsor, 2019). Alongside the positive effects of entrepreneurship on economic development, it was also found that productivity in enterprises which focused on entrepreneurial activities, has substantially risen. This indicates that entrepreneurial activities can bring "new energy" into the workplace, which can further contribute to overall business performance (Bjornskov, \& Foss, 2016). Also, it was found that entrepreneurial activities within SMEs can contribute to process improvements and innovation development (Schenkel, Farmer, \& Maslyn, 2019).

Furthermore, just how important is youth entrepreneurship? The answer to this question is evident when the youth unemployment rates are observed. Certainly, youth unemployment rates tend to be higher in developing countries, compared to developed countries. In addition, the size of the economy, and the total number of SMEs also affect youth unemployment rates (MarianaCristina, 2014). When youth unemployment rates are analyzed, it is evident that this rate of $27.5 \%$ in 2019 in Serbia is higher compared to the European Union average of $15.7 \%$, and even higher from some neighboring countries (ILOSTAT, 2020). Further data on youth unemployment rates for individual countries is presented in Table 1. 
D. Coćkalo Youth entrepreneurship development:

et al. A review of literature and ten-year research results

Table 1: Youth unemployment rates (YUR) in 2018 and 2019

\begin{tabular}{|l|c|c|}
\hline \multicolumn{1}{|c|}{ Country } & $\begin{array}{c}\text { Youth } \\
\text { unemployment } \\
\text { rates in 2018 }\end{array}$ & $\begin{array}{c}\text { Youth } \\
\text { unemployment } \\
\text { rates in 2019 }\end{array}$ \\
\hline Albania & $31.0 \% \%^{*}$ & $27 \%^{2)}$ \\
\hline $\begin{array}{l}\text { Bosnia and } \\
\text { Herzegovina }\end{array}$ & $46.7 \% * *$ & $33.8 \%^{2)}$ \\
\hline Bulgaria & $13.5 \% *$ & $8.9 \%^{2)}$ \\
\hline Croatia & $25.5 \% *$ & $16.6 \%^{2)}$ \\
\hline North Macedonia & $44.7 \% * *$ & $35.6 \%^{2)}$ \\
\hline Serbia & $32.1 \%$ & $27.5 \%^{2)}$ \\
\hline Montenegro & $29.1 \% *$ & $25.2 \%^{2)}$ \\
\hline Romania & $15.3 \% *$ & $16.8 \%^{1)}$ \\
\hline Hungary & $10.3 \%{ }^{*}$ & $11.4 \%^{1)}$ \\
\hline Greece & $39.5 \% * *$ & $35.2 \%^{2)}$ \\
\hline Germany & $6.4 \% *$ & $5.8 \%^{2)}$ \\
\hline Austria & $9.4 \% *$ & $8.5 \%^{2)}$ \\
\hline France & $20.9 \% *$ & $19.6 \%^{2)}$ \\
\hline
\end{tabular}

Source: ILOSTAT, 2020

In the second column (Youth unemployment rates in 2018) of Table 1., unemployment rates that are lower compared to Serbia are marked with a "**, while unemployment rates that are higher compared to Serbia are marked with “**”. In the third column (Youth unemployment rates in 2019) unemployment rates are colored following an increase or decrease of unemployment rates $\left({ }^{1)}\right.$ increase in unemployment rates; ${ }^{2)}$ - decrease in unemployment rates).

Based on the data given in Table 1, it is evident that the youth unemployment rates have decreased for nearly every specified country from 2018 to 2019. Serbia with a youth unemployment rate of $27.5 \%$ is not in an avid position compared to the other countries. Only Bosnia and Herzegovina, North Macedonia, and Greece have higher youth unemployment rates. Such inadequate rates indicate that the improvement of the entrepreneurial environment in Serbia would have potentially higher positive effects compared to low youth unemployment-rate countries.

Additionally, in Figure 1, youth unemployment rates for Serbia and non-EU neighboring countries and the EU average are presented from 2008 to 2019 (latest data).

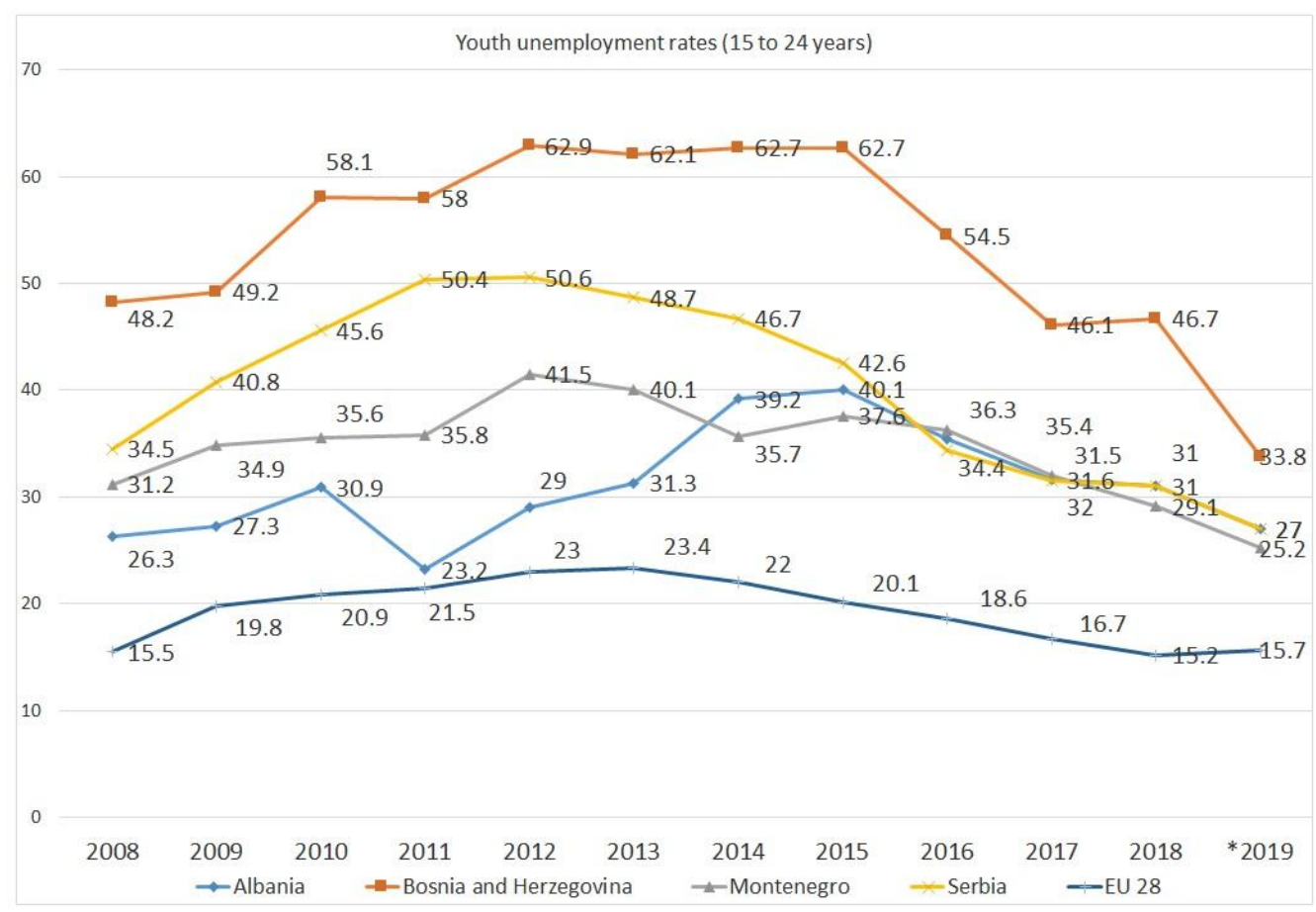

Figure 1: Youth unemployment rates Source: ILOSTAT, 2020

Based on Figure 1, it is evident that Serbia's unemployment rates are not favorable. However, the positive side is that there is a continuous decrease in youth unemployment rates over the years. This indicates that the changes are moving in the right direction. Generally speaking, high unemployment rates in Serbia may be the consequence of unfavorable political and socioeconomic environment (Ćcókalo, Đorđević, Nikolić, Stanisavljev, \& Terek, 2017). 
Furthermore, it was noted that youth entrepreneurship activities, education, and skill development are important for the overall increase in new businesses started by the youth. In addition to these factors, managerial skills have the potential to significantly improve chances for success when it comes to entrepreneurial activities (Gwija, Eresia-Eke, \& Iwu, 2014; Reyad, Musleh Al-Sartawi, Badawi, \& Hamdan, 2019). Also, besides the noted skills, individuals or groups who plan or conduct entrepreneurial activities should possess other skills and knowledge including but not limited to emotional intelligence, accounting, and project management. When it comes to external factors, it was argued that an unfavorable economic environment (such as in the majority of developing countries) may positively affect students to start their own business. More precisely, challenging business environments tend to motivate the youth to start their own business compared to developed countries (St-Jean et al., 2014). This is interesting as the European Union has significant support mechanisms for young entrepreneurs. These incentive means are noticeably higher compared to developing countries (Ćoćkalo, Đorđević, Nikolić, Stanisavljev, \& Terek, 2018), yet it seems that students from developing countries have higher levels of motivation. Additionally, in the majority of EU countries, entrepreneurship education was identified as an important aspect of overall economic growth. From here, it was identified that entrepreneurship education should be an integral part of the educational system (Jones, \& Iredale, 2014; Linton, \& Klinton, 2019). Interestingly, when it comes to the importance of entrepreneurship education, it was argued that values, attitudes, and beliefs should be prioritized, while technical business knowledge comes second.

Entrepreneurship education can have a significant effect on students' attitudes and intentions towards entrepreneurship. However, such education affects male and female students differently. Namely, female students were less likely to start their business and to involve (Westhead, \& Solesvik, 2016). In another study, it was discussed that demographic profile, entrepreneurial education, and even social background don't necessarily affect students' motives and intentions when it comes to starting own business, while occupational choices may have a strong influence on entrepreneurship intentions (Franco, Haase, \& Lautenschläger, 2010; Testa, \& Frascheri, 2015). Further, financial capital doesn't affect youth entrepreneurship in a significant way. However, it does hinder intentions for higher education (Sharma, 2014). It was also discussed that parents' occupation doesn't significantly affect entrepreneurship intentions, while social capital can significantly affect such intentions.

Entrepreneurship intentions are complex, and they can be affected by industrial settings (Smallbone, \& Welter, 2012); informal networks and bureaucratic levels (Smallbone, \& Welter, 2001); internships and education level (Campanella, Della Peruta, \& Del Giudice, 2013); a sense of sufficient knowledge and experience (Hulsink, \& Koek, 2014).

Based on this theoretical background, the following research questions are analyzed:

- Which factors affect youth entrepreneurship intentions and youth entrepreneurship development?

- What can be done to improve youth entrepreneurship intentions in Serbia?

This current study aims at answering these two noted research questions by analyzing the obtained results from the conducted research.

\section{TEN-YEAR RESEARCH REVIEW}

\section{Methodology review}

This study included 5670 participants - high school and university students from Serbia. The study was conducted for over ten years. The university students were enrolled in the University of Novi $\mathrm{Sad}$, and the University of Belgrade, the two biggest universities in Serbia. Students from the Belgrade Business and Arts Academy of Applied Studies also participated. A structured survey was used in the research which included dimensions of entrepreneurship including entrepreneurship attitudes, entrepreneurship intentions, and other factors which may influence the overall youth entrepreneurship dynamics (government incentives, bank loans, entrepreneurship skills family member occupation, etc.).

Due to the sheer number of participants, it can be argued that the sample is representative. The surveying was random in nature however the data analysis has indicated that the sample is suitable for this type of research. This type of approach can provide significant insight as the skewness and 
bias are practically annulled due to the periodicity of the sample taking and the overall number of participants.

Furthermore, when it comes to the existing body of literature in the domain of youth entrepreneurship and entrepreneurial activities overall, the subject is rather well investigated. As noted in the Theoretical background section there are a lot of influencing factors that may affect students' intentions to start their own business. However, there is few, if any, research that investigates students' attitudes and intentions over a long period of time (excluding meta-analyses) in a transitional setting. More precisely, long-term studies on youth entrepreneurship in developing countries are scarce compared to research from developed countries. This paper aims to fill this gap by analyzing a large sample size, where the data was collected in a tenyear study, where entrepreneurship intentions and attitudes are examined in Serbia which is a transitional country with challenging business environments

\section{Results review}

Based on the collected data and after the data analysis with various statistical tools and methods, interesting results were obtained:

- The majority of participants (43.9\%) agree or mostly agree that a working environment in a private business is better compared to public jobs. Further, $15.9 \%$ said they don't know, while $40.2 \%$ disagreed or mostly disagreed.

- The strong majority of participants (79.1\%) noted that they would start their own business.

- The main reasons for not starting their own business, the participants noted that they lack the right idea $(23.4 \%)$, they lack financial resources $(43.7 \%)$ and that the economic and political situation is uncertain $(37.6 \%)$. It is important to note multiple answers were acceptable, thus the percentage of the answers doesn't equal 100.

- The participants noted that they would mostly use their own/private resources to start their own business (65.9\%). $11.2 \%$ of the participants would use government incentives, $8.9 \%$ would apply for bank loans, and $14.2 \%$ would start their business with associated resources.

- When asked if they think that bank loans are affordable, the majority (56.1\%) answered No.
- Similarly, the majority of the participants $(56.9 \%)$ noted that they are not aware of government incentives for starting their own business.

- The participants noted that they think that the main limitations for entrepreneurial activities include lack of financial resources (77.5\%); unstable political and economic situation (76.3\%); limited market (26.4\%); disloyal competition (19.2\%); high tax rates $(56.5 \%)$; and other $(0.6 \%)$. It is important to note multiple answers were acceptable, thus the percentage of the answers doesn't equal 100 .

- Attitudes towards entrepreneurship - Age can be a predictor as older participants are more ready to start their own business. Participants who noted that private businesses are more successful are more likely to start their own business, while participants who noted that Participants who think that the working conditions in private enterprises are better than in other types of business are more ready to start their own business. Further, it was interesting to note that participants who have a family member that owns a business are LESS likely to start a business of their own.

- With another set of predictors, it was noted that if participants perceive bank loans as affordable, they are less likely to start their own business, as well as for incentive means. This can indicate the lack of trust in the government and its policies as well as the underlying economic uncertainty.

- Further, the data was analyzed following the suggestions of Boissin, Favre-Bonté, and FineFalcy (2017). The structured data indicated that students' intentions have a statistically significant and direct influence on intentions to start their own business. This is under previous studies (Audet, 2000; Boissin et al., 2009; Ozaralli, \& Rivenburgh, 2016).

- After conducting a latent class analysis in accordance with Akaike (1987), Schwarz (1978), Sclove (1987), and Lo, Mendell, \& Rubin (1993) three classes were noted. The first class included $56 \%$ of the participants, and includes females, whose family member owns a business, is not aware of incentive means, and thinks that there is too much uncertainty in the country.

- The second class includes $24 \%$ of the participants who are mainly female, who have some experience owning a business, think that there isn't a good environment in the country to 
start their own business and that there are incentive means which she is prepared to use.

- Finally, the third class includes $19.5 \%$ of the participants, with an equal percentage of males and females, who think that the situation in the country is not adequate to start own business, who have no experience in owning a business and that they heard about incentive means which they are ready to use.

Based on these results, it is evident that relations of entrepreneurial factors, including attitudes and intentions are complex. In the next section, the results are discussed, and the research questions are addressed.

\section{DISCUSSION}

In a previous study, it was discussed that if a family member is conducting entrepreneurial activities, and if the individual of that family member has managerial experience, unique knowledge, and unique knowledge of employees, then there is a large potential that these are predictive indicators which would lead to entrepreneurial success in the long-term where it was noted that an entrepreneur in the family, managerial experience, unique knowledge of employees, and unique knowledge of the entrepreneurs themselves can be addressed as predictive indicators to entrepreneurial success (Staniewski, 2016). Interestingly, the results of this current study are contradictory to the note finings, and it was found that if a family member owns a business, there is less possibility for the students to start their own business.

The importance of entrepreneurial activity lies in its potential to drive economic development and economic growth. This growth comes through innovation and new market value creation. Therefore, from here it is evident that an entrepreneur has to identify and act on profitable ideas that may occur on the market or are already present on the market (Dimova, \& Pela, 2018). Now, when it comes to youth entrepreneurship, it is important to add that knowledge itself is not enough when the goal is to create value and to improve economic prosperity. Namely, besides knowledge, the willingness of entrepreneurs who want to create value and the sheer innovativeness of specific ideas are more important, as these factors transpire into products and services alongside knowledge (Audretsch, Bönte, \&
Keilbach, 2008). Also, entrepreneurial activities can overcome barriers and "filters" which consists of cultural and socio-economic norms (Saraiva, \& Gabriel, 2016).

Furthermore, financial stability, institutional quality, perceived entrepreneurial skills, and even basic managerial skills are strong predictors of entrepreneurial activities. In addition to these predictors, small government, and the political and socio-economic environment in the country also influence entrepreneurship (Bosma, Content, Sanders, \& Stam, 2018). Certainly, adequate economic policies and a good, stable environment in the country are a common determinant of entrepreneurial activities and the development of entrepreneurship (Nicolae, Radu, \& Irina, 2017). Also, entrepreneurship education has a positive effect on students' attitudes towards starting their own business and overall entrepreneurship activities (Packham et al., 2010).

The main research reviewed in this paper indicated contradictory results when it comes to entrepreneurship attitudes and intentions. Namely, it was noted that students' attitudes have mainly a negative influence on students' intentions to start their own business. This means, that stronger positive attitudes more often lead to less entrepreneurial intentions. In this research, it was also noted that older participants were more ready to start their own business compared to younger participants. Also, participants who think that private enterprises make up a better working environment compared to public enterprises, are more likely to start their own business. Further, research questions noted at the beginning of the paper are addressed:

\section{- Which factors affect youth entrepreneurship intentions and youth entrepreneurship development?}

Based on the reviewed ten-year research, it is interesting to note that there seems to be a negative effect of students' attitudes on students' intentions on starting their own business. Also, based on the analyzed body of literature it can be argued that political and socio-economic factors also influence entrepreneurial activities. From the aspect of entrepreneurship education, it doesn't fully affect entrepreneurial intentions, as several other factors can influence entrepreneurial education outcomes. Motivation presence, emotional intelligence and emotional responses, past experiences, culture, social environment, and possessed skills can all 
affect entrepreneurial intent (Bagozzi, 1992). As it is almost impossible to isolate the impact of entrepreneurial education on entrepreneurship intentions, it is necessary to always take into consideration the wide array of factors, which may affect entrepreneurial behavior.

- What can be done to improve youth entrepreneurship intentions?

With the goal to improve youth entrepreneurship the following suggestions are proposed:

- Reduction and simplification of new law and policy frequency. This would give "breathing" room for the entrepreneurs to focus on other aspects of the business, rather than extensive paperwork.

- Introducing entrepreneurship courses to high school students and create a plan for introducing entrepreneurship in elementary schools. This would increase youth entrepreneurship potential in the long-term.

- Reduce taxes for start-ups and introduce flexible solutions for enterprises who do not yet fully "stand on their feet". Strict policies should be included to prevent the exploitation of startup-based tax reductions.

- Developing online platforms where existing SMEs and new potential entrepreneurs can network. This approach may lead to partnerships, investments, innovation, and overall economic development.

- Creating partnerships with existing enterprises where a student could be working as interns. These could be paid internships or part-time jobs.

The proposed solution for youth entrepreneurship can be further detailed in accordance with the specific factors and metrics of a given situation (country, level of education, type of industry, etc.). Overall, the importance of youth entrepreneurship and overall entrepreneurial activities lies in its potential to increase economic growth and economic development. However, it is important to take into consideration that there are indications that strong and stable economies tend to "nurture" a larger number of entrepreneurs compared to developing countries. This may be due that stable and prosperous economies have a more stimulating and motivating environment for entrepreneurial activities.

\section{CONCLUSION}

Based on the literature review and the ten-year research review, it can be concluded that youth entrepreneurship positively affects economic development. Youth entrepreneurship and entrepreneurship overall reduce unemployment rates, increases the creation and circulation of value on various markets, increases competitiveness on a national level, and overall improves the standard of living. The ten-year research review indicated that students' attitudes are negatively correlated to students' intentions to start their own business. This is interesting and contradictory to most other findings. It is clear that other factors may affect the process of attitude transformation into an intention. These may be external factors or close societal factors. Nonetheless, this invites future research.

This current paper significantly contributes to the existing body of literature as it thoroughly addresses factors that affect youth entrepreneurship and entrepreneurship overall. In addition, a tenyear study is reviewed which sheds additional light on the entrepreneurship dynamics which are present in a transitional setting. Form here, additional studies can be conducted, as this paper provides a solid basis for research in the domain of youth entrepreneurship and entrepreneurship overall. Fellow scholars can address this paper for their own research and use it as an adequate starting point for their own research.

The main limitation of this paper is the lack of a non-English literature review. This may create minor bias. However, the reviewed literature also included studies conducted in non-English speaking countries, thus this limitation is not severe. For future research it is recommended to include additional meta-analysis across several categories such as, but not limited to, industry, year of publication, geographical location, demographics, etc. This would further expand the current body of literature.

\section{ACKNOWLEDGEMENT}

This paper has been supported by the Provincial Secretariat for Higher Education and Scientific Research of the Autonomous Province of Vojvodina, number: 142-451-2139/2019-01. 
D. Coćkalo Youth entrepreneurship development:

et al. A review of literature and ten-year research results

\section{REFERENCES}

Acs, Z., J., Desai, S., \& Hessels, J. (2008). Entrepreneurship, economic development and institutions. Small Business Economics, 31(3), 219234. doi:10.1007/s11187-008-9135-9

Ahlstrom, D., Chang, A. Y., \& Cheung, J. S. (2019). Encouraging entrepreneurship and economic growth. Journal of Risk and Financial Management, 12(4), 178. doi:10.3390/jrfm12040178

Akaike, H. (1987). Factor analysis and AIC. Psychometrika, 52(3), 317-332. doi: 10.1007/978-14612-1694-0_29

Antoncic, B., \& Hisrich, R. D. (2004). Corporate entrepreneurship contingencies and organizational wealth creation. Journal of Management Development, 23(6), 518-550. doi:10.1108/02621710410541114

Audet, J. (2000). Evaluation of two approaches to entrepreneurship education using an intention-based model of venture creation. Academy of Entrepreneurship Journal, 6(1), 58-63. doi: 10.1.1.200.7367

Audretsch, D. B., Bönte, W., \& Keilbach, M. (2008). Entrepreneurship capital and its impact on knowledge diffusion and economic performance. Journal of Business Venturing, 23(6), 687-698. doi:10.1016/j.jbusvent.2008.01.006

Bakator, M., Đorđević, D., Ćoćkalo, D., Nikolić, M., \& Vorkapić, M. (2018). Lean startups with industry 4.0 technologies: Overcoming the challenges of youth entrepreneurship in Serbia. Journal of Engineering Management and Competitiveness (JEMC), 8(2), 89101. UDC: 005.96(497.11)

Bagozzi, R. (1992). The Self-Regulation of Attitudes, Intentions, and Behavior. Social Psychology Quarterly. 55. 178. doi:10.2307/2786945

Bjornskov, C., \& Foss, N. J. (2016). Institutions, Entrepreneurship, and Economic Growth: What Do We Know and What Do We Still Need to Know? Academy of Management Perspectives, 30(3), 292315. doi:10.5465/amp.2015.0135

Boissin, J. P., Branchet, B., Emin, S., \& Herbert, J. I. (2009). Students and entrepreneurship: a comparative study of France and the United States. Journal of Small Business \& Entrepreneurship, 22(2), 101-122. doi: 10.1080/08276331.2009.10593445

Boissin, J. P., Favre-Bonté, V., \& Fine-Falcy, S. (2017). Diverse impacts of the determinants of entrepreneurial intention: three submodels, three student profiles. Revue de lEntrepreneuriat, 16(3), 17-43. doi: 10.3917/entre.163.0017

Bollingtoft, A., Ulhoi, J. (2005). The networked business incubators - leveraging entrepreneurial agency. Journal of Business Venturing, 20(2): 165 290. doi: 10.1016/j.jbusvent.2003.12.005

Bosma, N., Content, J., Sanders, M., \& Stam, E. (2018). Institutions, entrepreneurship, and economic growth in Europe. Small Business Economics, 51(2), 483499. doi:10.1007/s11187-018-0012-x

Bostan, I., Lazar, C. M., Asalos, N., Munteanu, I., \& Horga, G. M. (2019). The three-dimensional impact of the absorption effects of European funds on the competitiveness of the SMEs from the Danube Delta. Industrial Crops and Products, 132, 460-467. doi:10.1016/j.indcrop.2019.02.053

Bruton, G. D., Ahlstrom, D., \& Obloj, K. (2008). Entrepreneurship in emerging economies: Where are we today and where should the research go in the future. Entrepreneurship Theory and Practice, 32(1), 1-14. doi: 10.1111/j.1540-6520.2007.00213.x

Campanella, F., Della Peruta, M. R., \& Del Giudice, M. (2013). The Role of Sociocultural Background on the Characteristics and the Financing of Youth Entrepreneurship. An Exploratory Study of University Graduates in Italy. Journal of the Knowledge Economy, 4(3), 244-259. doi:10.1007/s13132-013-0157-4

Carree, M. A., \& Thurik, A. R. (2010). The impact of entrepreneurship on economic growth. In Handbook of entrepreneurship research (pp. 557-594). Springer, New York, NY. doi: 10.1007/978-1-44191191-9_20.

Choi, Y.R. \& Shepherd, D.A. (2004). Entrepreneurs' decisions to exploit opportunities. Journal of Management, 30(3), 377-395. doi: 10.1016/j.jm.2003.04.002

Ćoćkalo, D., Đorđević, D., Nikolić, M., Stanisavljev, S., $\&$ Terek, E. (2017). Analysis of possibilities for improving entrepreneurial behaviour of young people: Research results in Central Banat district. Journal of Engineering Management and Competitiveness (JEMC), 7(2), 97-108. UDC: 005.961:005.914.3-053.91(497.113 Banat).

Ćoćkalo, D., Đorđević, D., Nikolić, M., Stanisavljev, S., \& Terek, E. (2018). An exploratory study of relationship between entrepreneurship and economic development - Central Banat Region Research Results. VIII International Symposium Engineering Management and Competitiveness 2018 (EMC 2018), 9-14. Zrenjanin, SRB: University of Novi Sad, Technical faculty "Mihajlo Pupin". ISBN 97886-7672-307-2.

Ćoćkalo, D., Đorđević, D., Nikolić, M., Stanisavljev, S., Terek, E., \& Bakator, M. (2019). The needs of the economy and encouraging entrepreneurship of young people in Central Banat Region. Paper presented at the Ninth International Symposium "Engineering Management and Competitiveness EMC 2019, 15-20. Zrenjanin, SRB: University of Novi Sad, Technical faculty "Mihajlo Pupin". ISBN 978-86-7672-321-8.

Crudu, R. (2019). The role of innovative entrepreneurship in the economic development of EU member countries. Journal of Entrepreneurship, Management and Innovation, 15(1), 35-60.

Dimova, R., \& Pela, K. (2018). Entrepreneurship: Structural Transformation, Skills and Constraints. 
Small Business Economics 51(1), 203-220. doi: 10.1007/s11187-017-9916-0

Doran, J., McCarthy, N., \& O'Connor, M. (2018). The role of entrepreneurship in stimulating economic growth in developed and developing countries. Cogent Economics \& Finance, 6(1). doi:10.1080/23322039.2018.1442093

Franco, M., Haase, H., \& Lautenschläger, A. (2010). Students' entrepreneurial intentions: an inter-regional comparison. Education + Training, 52(4), 260-275. doi:10.1108/00400911011050945

Gwija, S. A., Eresia-Eke, C., \& Iwu, C. G. (2014). The Link between Entrepreneurship Education and Business Success: Evidence from Youth Entrepreneurs in South Africa. Journal of Economics, 5(2), 165-175. doi:10.1080/09765239.2014.11884993

Hulsink, W., \& Koek, D. (2014). The young, the fast and the furious: a study about the triggers and impediments of youth entrepreneurship. International Journal of Entrepreneurship and Innovation Management, 18(2-3), 182-209.

International Labour Organization, ILOSTAT database. Data retrieved in September 2020. Available at: https://data.worldbank.org

Jones, B., \& Iredale, N. (2014). Enterprise and entrepreneurship education: towards a comparative analysis. Journal of Enterprising Communities: People and Places in the Global Economy, 8(1), 3450. doi:10.1108/jec-08-2012-0042

Lamrani, R., Abdelwahed, E. H., Chraibi, S., Qassimi, S., Hafidi, M., \& El Amrani, A. (2016). Serious Game to Enhance and Promote Youth Entrepreneurship. Europe and MENA Cooperation Advances in Information and Communication Technologies, 77-85. doi:10.1007/978-3-319-465685_8

Linton, G., \& Klinton, M. (2019). University entrepreneurship education: a design thinking approach to learning. Journal of Innovation Entrepreneurship 8(3). doi:10.1186/s13731-0180098-Z

Lo, Y., Mendell, N. R., \& Rubin, D. B. (2001). Testing the number of components in a normal mixture. Biometrika, 88(3), 767-778. doi: 10.1093/biomet/88.3.767

Khalid, N., Ahmed, U., Tundikbayeva, B., \& Ahmed, M. (2019). Entrepreneurship and organizational performance: Empirical insight into the role of entrepreneurial training, culture and government funding across higher education institutions in Pakistan. Management Science Letters, 9(5), 755770. doi:10.5267/j.msl.2019.1.013

Man, T. W. ., Lau, T., \& Chan, K. . (2002). The competitiveness of small and medium enterprises. Journal of Business Venturing, 17(2), 123-142. doi:10.1016/s0883-9026(00)00058-6

Manolova, T. S., Edelman, L. F., Shirokova, G., \& Tsukanova, T. (2019). Youth entrepreneurship in emerging economies: can family support help navigate institutional voids? Journal of East-West Business, 1-33. doi:10.1080/10669868.2019.1624672

Mariana-Cristina, G. (2014). Entrepreneurship, a solution to improve youth employment in the European Union. Management Strategies Journal, 26(4), 580-588. doi: 10.1007/978-1-4419-1191-9_20

Neneh, B. N. (2019). From entrepreneurial intentions to behavior: The role of anticipated regret and proactive personality. Journal of Vocational Behavior. doi:10.1016/j.jvb.2019.04.005

Nicolae, M., Radu, L. U. P. U., \& Irina, I. O. N. (2017). What matters for entrepreneurship? A global view on its determinants. Romanian Journal of Economic Forecasting, 20(2). ISSN 2537-6071.

Olugbola, S. A. (2017). Exploring entrepreneurial readiness of youth and startup success components: Entrepreneurship training as a moderator. Journal of Innovation \& Knowledge, 2(3), 155-171. doi:10.1016/j.jik.2016.12.004

Ozaralli, N., \& Rivenburgh, N. K. (2016). Entrepreneurial intention: antecedents to entrepreneurial behavior in the USA and Turkey. Journal of Global Entrepreneurship Research, 6(1), 3. doi:10.1186/s40497-016-0047-x

Packham, G., Jones, P., Miller, C., Pickernell, D., \& Thomas, B. (2010). Attitudes towards entrepreneurship education: a comparative analysis. Education + Training, 52(8/9), 568-586. doi:10.1108/00400911011088926

Pinillos M.-J., \& Reyes, L. (2011). Relationship between individualist-collectivist culture and entrepreneurial activity: evidence from Global Entrepreneurship Monitor data. Small Business Economics, 37(1), 23-37. doi: 10.1007/s11187-0099230-6

Reyad, S. M. R., Musleh Al-Sartawi, A., Badawi, S., \& Hamdan, A. (2019). Do entrepreneurial skills affect entrepreneurship attitudes in accounting education? Higher Education, Skills and Work-Based Learning. doi:10.1108/heswbl-01-2019-0013

Saraiva, H. I., \& Gabriel, V. (2016). Entrepreneurship and education in the European Union: Student's perception on the subject. The International Journal of Management Science and Information Technology (IJMSIT), 22, 40-58.

Schenkel, M. T., Farmer, S., \& Maslyn, J. M. (2019). Process improvement in SMEs: The impact of harmonious passion for entrepreneurship, employee creative self-efficacy, and time spent innovating. Journal of Small Business Strategy, 29(1), 71-84.

Schwarz, G. (1978). Estimating the dimension of a model. The Annals of Statistics, 6(2), 461-464. doi:10.1214/aos/1176344136

Sclove, S. L. (1987). Application of model-selection criteria to some problems in multivariate analysis. Psychometrika, 52(3), 333-343. doi: 10.1007/BF02294360

Sergi, B. S., Popkova, E. G., Bogoviz, A. V., \& Ragulina, J. V. (2019). Chapter 1 Entrepreneurship 
D. Coćkalo Youth entrepreneurship development:

et al. A review of literature and ten-year research results

and Economic Growth: The Experience of

Developed and Developing Countries.

Entrepreneurship and Development in the 21st

Century, 3-32. doi:10.1108/978-1-78973-233-

720191002

Shahab, Y., Chengang, Y., Arbizu, A. D., \& Haider, M. J. (2018). Entrepreneurial self-efficacy and intention: do entrepreneurial creativity and education matter? International Journal of Entrepreneurial Behavior \& Research. doi:10.1108/ijebr-12-20170522

Sharma, L. (2014). Impact of family capital \& social capital on youth entrepreneurship - a study of Uttarakhand state, India. Journal of Global Entrepreneurship Research, 4(1). doi:10.1186/s40497-014-0014-3

Smallbone, D. \& Welter, F. (2001) The Distinctiveness of Entrepreneurship in Transition Economies. Small Business Economics 16(4), 249262. doi:10.1023/A:1011159216578

Smallbone, D., \& Welter, F. (2012). Entrepreneurship and institutional change in transition economies: The Commonwealth of Independent States, Central and Eastern Europe and China compared.

Entrepreneurship \& Regional Development, 24(3-4), 215-233. doi:10.1080/08985626.2012.670914

St-Jean, É., Nafa, A., Tremblay, M., Janssen, F., Baronet, J., \& Loué, C. (2014). Entrepreneurial intentions of university students: an international comparison between African, European and Canadian students. International Journal of Entrepreneurship and Innovation Management, 18(2-3), 95-114. doi: 10.1504/IJEIM.2014.062878

Staniewski, M. W. (2016). The contribution of business experience and knowledge to successful entrepreneurship. Journal of Business Research, 69(11), 5147-5152.

doi:10.1016/j.jbusres.2016.04.095
Stephan U., Uhlaner L.M., 2010. Performance-based vs socially supportive culture: A ross-national study of descriptive norms and entrepreneurship. Journal of International Business Studies, 41(8),1347-1364. doi: $10.1057 /$ jibs.2010.14

Testa, S., \& Frascheri, S. (2015). Learning by failing: What we can learn from un-successful entrepreneurship education. The International Journal of Management Education, 13(1), 11-22. doi:10.1016/j.ijme.2014.11.001

Thompson, E. R. (2009). Individual Entrepreneurial Intent: Construct Clarification and Development of an Internationally Reliable Metric. Entrepreneurship Theory and Practice, 33(3), 669-694. doi:10.1111/j.1540-6520.2009.00321.x

Walsh, J., \& Winsor, B. (2019). Socio-cultural barriers to developing a regional entrepreneurial ecosystem. Journal of Enterprising Communities: People and Places in the Global Economy. doi:10.1108/jec-112018-0088

Wellalage, N. H., \& Fernandez, V. (2019). Innovation and SME finance: Evidence from developing countries. International Review of Financial Analysis. doi:10.1016/j.irfa.2019.06.009

Westhead, P., \& Solesvik, M. Z. (2016). Entrepreneurship education and entrepreneurial intention: do female students benefit?. International Small Business Journal, 34(8), 979-1003. doi: $10.1177 / 0266242615612534$

Wilson, F., Kickul, J., \& Marlino, D. (2007). Gender, entrepreneurial self-efficacy, and entrepreneurial career intentions: Implications for entrepreneurship education. Entrepreneurship Theory and Practice, 31(3), 387-406. doi:10.1111/j.15406520.2007.00179.x 


\section{RAZVOJ PREDUZETNIŠTVA MLADIH: PREGLED LITERATURE I DESETOGIŠNJEG ISTRAŽIVANJA}

Preduzetništvo igra značajnu ulogu u ekonomskom razvoju. Dalje, koncept preduzetništva je argumentovan kao važan činilac u sveukupnom ekonomskom rastu. Usled velike stope nezaposlenosti mladih kako u zemljama u razvoju tako i u razvijenim zemljama, unapređenje okruženja za razvoj preduzetničkih aktivnosti je imperativ za poboljšanje preduzetništva mladih. U ovom preglednom radu analizira se desetogodišnje istraživanje sprovedenog u okviru preduzetništva mladih. $U$ tom istraživanju učestvovalo je ukupno 5670 učesnika - srednjoškolaca i studenata iz Republike Srbije. Dodatno, analizirani su i drugi literaturni izvori u domenu preduzetništva. Glavni cilj ovog rada je identifikovanje i određivanje potencijala stavova studenata prema preduzetništvu i njihovih namera kada je u pitanju pokretanje sopstvenog biznisa. Rad analizira postojeću literaturu u cilju predstavljanja temeljno istraživane i koncizno definisane "slike" u domenu preduzetništva mladih. Na ovaj način se efektivno kreira čvrsta osnova za buduća istraživanja.

Ključne reči: Preduzetništvo mladih, Razvoj, Stavovi, Namere, Poslovanje, Srbija 